\title{
RECOGNITION OF PRIOR LEARNING (RPL) AND SUPPORT: ARE THE LEARNING NEEDS OF RPL FIRST-YEAR STUDENTS DIFFERENT?
}

\section{Glynnis Zena Dykes}

\section{INTRODUCTION}

RPL was first established in the United States during the late 1960s and was initially used in their formal education and training sector (Dyson \& Keating, 2005). Certain international higher education institutions (HEIs) have been using Recognition of Prior Learning (RPL) for more than 30 years, particularly in the USA, Canada, Northern Ireland, Britain and Australia (Gawe cited in Moore \& Van Rooyen, 2002; Geyser, 2001). The origins of RPL in South Africa can be traced to several projects and policy-making structures established by the trade union movement and the ANC in the struggle for liberation in the late 1980s (SAQA, 2002:9). RPL was placed on the South African educational agenda in the early 1990s prior to the birth of South Africa's new democracy (Breier, 2007). Its establishment was strongly motivated by the trade union movement, for example, the Congress of South African Trade Unions (COSATU), to recognise the knowledge and skills of millions of previously disadvantaged workers and the movement fought for the rights of workers to gain access to HEIs to improve their chances of promotion and employment. In this context RPL was seen as a mechanism to redress sociopolitical imbalances of the past (Cretchley \& Castle, 2001). The proliferation of RPL into HEIs, globally and locally, suggests that using only traditional access as the indicator for access to HEIs and success is "inadequate and outdated" (Kistan, 2002:171).

The courage to apply and be accepted into a degree programme at a university is generally experienced as empowering and confidence building. The future for such a candidate seems bright and full of promise. To a candidate who has gained access to a university programme through the avenue of RPL, this is all the more heartening. These candidates would previously have been barred from access to a university for not meeting the traditional access requirements (that is, matriculation exemption until 2007 and a points system from 2008), but now could gain access through RPL without a matriculation exemption or certificate. Harris (2000:39) asserts that "RPL is essentially a fast-tracking device - a boundary-crossing or a boundaryjumping mechanism". In view of Harris's assertion, should it be assumed that those students who "boundary-jumped" the rigours of traditional high school education would need "added" (i.e. in addition to those generic support programmes already in existence in HEIs) academic support?

The rationale for research into whether RPL students required additional academic support lies in the background of post-1994 education policy in South Africa; the retention, throughput and success of RPL Social Work students at the University of the Western Cape; and social work being declared a scarce skill. These concepts are discussed below.

\section{South African education policy (post-1994)}

The exclusive power exerted in apartheid and its concomitant racialised policies were in direct contrast to the notion and value of inclusivity and accessibility within a human rights and social justice perspective. Chapter 3 of the White Paper on Education and Training (1995:8) entitled "Transforming the Legacy of the Past" holds that the task of government is to create a system that will fulfil the vision to "open the doors of learning". It emphasises the focus on the 
"redress of educational inequalities among those sections of our people who have suffered particular disadvantages" (1995:11), and that access will be opened for those whose "academic or career paths have been needlessly blocked because their prior knowledge (acquired informally or by work experience) has not been assessed and certified" (1995:6).

South Africa legislated its acceptance of the international approach of RPL to use as a mechanism to redress past barriers to accessing higher education institutions, the resulting acknowledgement of the particularly damaging effects of apartheid on the education of the majority of people. The South African Higher Education Act 101 (1997:28) accordingly confirmed that "The admission policy of a higher education institution must provide appropriate measures for the redress of past inequalities and may not unfairly discriminate in any way". The South African Qualifications Authority (SAQA) gazetted the development and implementation of RPL, contending that RPL is vital in the development of an appropriate education and training system for South Africa (SAQA, 2002:9).

It is important to note that RPL is not exclusively extended to those who have been directly affected by apartheid legislation. The legacy of inequality continues to have its impact on the lives of the majority of people with regard to education and training. As at 2002, 7 million people were in semi-/unskilled jobs or unemployed. Most had severely limited opportunities for formal education (SAQA, 2002:9). Kistan (2002:169) calculated that the demand for workers with tertiary education increased by $2028 \%$ at this time, but that HEIs were not meeting this need.

\section{Retention and throughput of RPL Social Work students at the University of the Western Cape}

The University of the Western Cape (UWC) had "opened its doors of learning" to those prospective students who have been particularly marginalised by the socio-political restrictions of apartheid and have struggled to complete their high school qualification in order to have gained access to higher education institutions (UWC Division of Lifelong Learning). In its General Calendar the University states that it may grant access to students without matriculation, but with relevant work or prior learning experiences (UWC General Calendar, 2008:49).

Various academic and professional programmes within the university were therefore required to expand their entry requirements to include RPL principles. The Social Work programme at UWC also responded and began accepting students without a matriculation qualification into its programme from 2003. Because of its particular teaching and learning philosophy of nondiscrimination and social justice framework (UWC University Calendar Part VIII, 2008:179189), the Social Work programme became a willing receptacle for RPL students. It was considered that RPL students would bring their life and work experiences into the class and would be able to contextualise the learning information without having had the benefit of matriculation qualifications.

There is a likelihood of the RPL students feeling lost or mismanaged without academic support strategies for their learning needs, once access was granted. There is an assumption that the generic academic support structures - for example, within the UWC context, the writing centre and various module tutorial programmes - were sufficient for the learning needs of all the students regardless of the access granted. In New Zealand, where educational backgrounds are differentiated in similar ways as in South Africa, student success is distinguished by retention, 
persistence, completion and graduation, while the opposite can be termed withdrawal, noncompletion, drop-out, attrition and departure (New Zealand Ministry of Education, 2005:3).

Using these criteria, statistics of Social Work RPL students at UWC from 2003 to 2007 reflect the following (Table 1):

\section{TABLE 1}

SOCIAL WORK RPL STUDENTS AT UWC 2003-2007

\begin{tabular}{|c|c|c|c|c|c|}
\hline $\begin{array}{c}\text { Total } \\
\text { number } \\
\text { applied }\end{array}$ & $\begin{array}{c}\text { Total } \\
\text { number } \\
\text { approved }\end{array}$ & $\begin{array}{c}\text { Students in } \\
\text { programme } \\
\text { currently }\end{array}$ & $\begin{array}{c}\text { Graduated } \\
\text { students }\end{array}$ & $\begin{array}{c}\text { Did not } \\
\text { continue }\end{array}$ & $\begin{array}{c}\text { Limit imposed } \\
\text { by the university } \\
\text { per year }\end{array}$ \\
\hline 43 & 19 & 12 & 3 & 4 & 5 \\
\hline
\end{tabular}

In terms of the statistical data 50\% completed their degree within the allotted time period (two students out of four). One student dropped out in the first year and the other student cited finances and illness as reasons for having to repeat a year, but graduated one year later. This student had maintained a B aggregate. Of the 12 students currently in the programme, three RPL students had to repeat a year level. From the quantitative data a particular position regarding academic support for Social Work RPL students can be inferred, which is that the RPL students have performed satisfactorily without added support. However, the experiences or opinions of RPL students were not elicited to provide qualitative data on their learning and support needs, first-year RPL students in particular. The lack of qualitative data is therefore identified as a gap.

\section{Social work as a scarce skill}

Social work as a profession was included in the National Master Scarce Skills List for South Africa (2007) by the Minister of Labour. In publishing this List, the Minister declared a range of scarce and critical skills that hamper socio-economic activity in South Africa. The data were obtained from a number of SETA (Sector Education and Training Authority, which are statutory bodies that oversee education and training in particular sectors of industry, specifically in terms of learnerships), skills plans and various government departments. In terms of social work, a shortage of 5000 was calculated. A number of figures have been bandied about. Earle (2007) has calculated that an additional 7631 social workers would be needed to undertake the transformation of social service delivery. Yet the then Minister of Social Development, Zola Skweyiya, in his address at the $34^{\text {th }}$ Biennial Congress of the International Schools of Social Work (IASSW) in Durban on 20 July 2008, stated that 16000 social workers were needed in order to implement the requirements of the new Children's Act 38 of 2005 (Independent Online, 2008; Skweyiya, 2008). In terms of these figures RPL can be one mechanism that can also be used to increase the numbers of social workers needed in accordance with the number of social workers that need to be recruited.

\section{RESEARCH CONTEXT}

Osman and Castle (2006:515) ponder how "space can be made for adult learners to flourish in higher education". They contend that legislation and institutions see access and the numbers as the ultimate criteria, and a holistic process of integrating access with curriculum changes, learners' motivation and workplace support. All of these, they say, impact on retention and throughput. To ascertain how adult part-time students perceived support, February and Koetsier (2007) undertook a study at UWC with part-time adult students. They found that students 
defined support as internal to themselves and their family situation, and viewed support from the University as extra. In their study investigating the level of student adjustment to an academic environment via RPL in Australia, Cantwell and Scevak (2004) found that risk factors needed to be determined and that a form of support, other than tutorials, may be compulsory.

A gap has been identified for literature on RPL-specific support at HEIs. It could be concluded that HEIs did not have any supportive structures specifically established for RPL students in their first year of study. However, the general importance of learner support was acknowledged (Cantwell \& Scevak, 2004; February \& Koetsier, 2007; Zuhairi, Adnan \& Thaib, 2007). A further gap was qualitative research with RPL students and Social Work students in particular.

The purpose of the present study was to research the phenomenon of academic support for RPL students by obtaining their verbal descriptions and perceptions of their prior learning experiences and the support they felt they needed. The themes common to RPL and traditional access students, as well as differences, will be further elucidated.

From the above, the research questions applicable to the aspects to be studied can be posited as follows:

- What are Social Work students' prior learning histories and experiences?

- What are these students' opinions about the support required from, and their experiences of support provided by, their institution (UWC)?

\section{RPL LEARNING THEORIES}

The philosophical foundations of RPL are located in (i) the educational philosophy of John Dewey (1859-1952), who believed in a learner-focused rather than the traditional teacherfocused curriculum; (ii) the social psychology of Kurt Lewin (1890-1947), who expanded knowledge on groups, experiential learning and action research; and (iii) the cognitive developmental theory of Jean Piaget (1896-1980), who designed a model of child development and learning (Conner, 2004; Moore \& Van Rooyen, 2002:293). These authors concluded that the learning theories posited by Dewey, Lewin and Piaget view learning as part of a lifelong developmental process, which is individual and unique, and integrated into learning experiences. RPL therefore underscores experiential learning and emphasises adult learning principles.

\section{EXPERIENTIAL LEARNING}

Experiential learning simply means to learn from experience (Amstutz, 1999:24). This learning theory was based on the work of David Kolb (1984) (cited in Atherton, 2005; Moore \& Van Rooyen, 2002). According to Kolb, experience should be regarded as an input and learning as an output. He contends that experience is not sufficient for learning, but that reflection is needed for learning to take place. This principle is contained in a model he designed on adult learning processes based on the work of Kurt Lewin. This model involves four stages (Atherton, 2005; Moore \& Van Rooyen, 2002). The first stage is Concrete Experience, which refers to practical experience that jettisons learning (the process of "apprehension"). This is followed by Reflective Observation, where the learner thinks about what the experiences means. In Abstract Conceptualisation (the process of "comprehension") the learner transforms the experience into learning by creating ideas and generalisations about the experience or the application of theories to it ("thinking connotations"). Active Experimentation transforms the theory and ideas into learning by testing it in practice ("using denotation"). The process of 
experiential learning can begin at any of the stages and is continuous, which means you can go through the cycle many times during a learning situation. Atherton (2005) summarises the model into two ways of knowing, i.e. by direct experiences (apprehension) or knowing about (comprehension); and two ways of understanding or transforming knowledge, i.e. by thinking connotation (reflective observation) or by using denotation (active experimentation).

These steps would increase levels of learning, understanding and insight, which are learning outcomes. Therefore, experiential learning is more difficult to assess, according to Ralphs and Buchler (1998:10), because it highlights the importance of the context in which learning is made in the lives of adults.

\section{ADULT LEARNING THEORY}

Pedagogy (or content model) literally means the art and science of teaching children, but is taken to mean a more teacher-focused form of education for both adults and children (Conner, 2004:1). In contrast to the principles of pedagogy, Malcolm Knowles was the first to focus on the adult learner and proposed andragogy (or process model) (Conner, 2004). The initial meaning was "the art and science of helping adults learn"; this was later revised to mean "learner-focused education for people of all ages" (Conner, 2004:2; Osman \& Castle, 2006:515). Although andragogy usually is dependent on the group for learning resources and support, it is not expounded upon. Knowles's notion of self-directed learning involves learners as leaders in their assessment of their needs and learning areas. He believed that self-directed learning was a basic life competency especially for adults (Amstutz, 1999:23; Cretchley \& Castle, 2001). Importantly, Knowles believed that the experiences of adults (including knowledge, focus, application, self-discipline, motivation and self-knowledge) were the focal point of learning (Cretchley \& Castle, 2001:493, 497).

However, self-directed learning and the use of a learning contract have been criticised as not befitting the South African educational context because of the underlying assumption they carry. They assume "critical self-awareness on the part of learners, as well as a high level of academic literacy" (Amstutz; 1999:23; Cretchley \& Castle, 2001:493). There is also an assumption that the prerequisite resources and tutors are available for support and guidance. This, according to Cretchley and Castle (2001), has caused confusion led to unmet expectations. Furthermore, they contend that a new learner may lack the necessary experience in which to make decisions about their learning needs and objectives. Objectives are mostly predetermined, especially in a course like Social Work within the context of outcomes-based education. Even Knowles had to admit that self-diagnosing learning needs in groups of more than 30 was cumbersome (Cretchley \& Castle, 2001). It is precisely the "exclusion of context" that is particularly criticised as having limited the application of this theory (Amstutz, 1999:23; Ralphs \& Buchler, 1998:10).

\section{PRIOR LEARNING HISTORIES}

Researchers and educational institutions have linked RPL to lifelong learning (Dyson \& Keating, 2005:ix; Halifax Declaration for the Recognition of Prior Learning, 2001; UWC Division of Lifelong Learning). Lifelong learning is an approach to re-attach the link between learning and real life (Evans, 2006). The focus would be on the kinds of abilities and knowledge gained throughout the lifespan of the person as well as the valuing of the many forms of learning, for example, through family, community, and work. Rochford (2007:93) identified this as mode three learning and explained it as follows: "Out-of-school experiences in trans-disciplinary environments encompassing the home, the community and the workplace 
become important maturing learning events in a holistic process of lifelong learning." It is not life experiences that is the focus of assessment, however, but the learning that has taken place as a result of undergoing these life experiences (Ralphs \& Buchler, 1998:10). The importance for the study is the kind of learning that is derived from ordinary experiences, which must be brought from the sidelines to the mainstream in terms of what Rochford (2007) describes as "lifeplace learning".

\section{ACADEMIC (LEARNING) NEEDS AND SUPPORT}

In extolling the principles of open learning, the SA White Paper on Education and Training (1995:8) denotes learner support as both a principle and part of the quality assurance assessment. Geyser (2001:31) states that "Adult learners who have learnt a great deal from life, and who are going into higher education for the first time, will need an environment that is both supportive and challenging". Cretchley and Castle (2001:499) confirm, furthermore, that in addition to academic support, RPL in higher education will need trained assessors and counsellors.

In a study undertaken by Zuhairi et al. (2007) at Universitas Terbuka in Indonesia, contextualised within distance learning, they assert that the aim of learner support is to facilitate the learning needs of students to enable them to continue with their learning programme.

Research commissioned by the New Zealand Ministry of Education was undertaken to determine the impact of student support services on outcomes in undergraduate tertiary study and to provide a guide as to the most effective types of support. According to the research, key features of effective student support can be divided into two streams: ways of integrating students into existing institutional cultures (Osman \& Castle, 2006:517) and ways which challenge HEIs to address the changing academic and cultural needs of their students. In terms of student integration, their research recommended, amongst other things, that: institutions have administrative processes and environments that are appropriate and organisationally sound; academic counselling and guidance are provided so that students apply and register for appropriate courses; teachers (lecturers) have positive and encouraging demeanours; orientation and induction programmes are created for academic and social integration; and supplemental instruction, peer tutoring and mentoring services are provided. In terms of institutional adaptation, the following recommendations are highlighted: institutional structures, processes and policies are free of discrimination to ensure students are treated equitably and respectfully; and the institution has structures in place of the different learning needs and cultures for different students (New Zealand Ministry of Education, 2005:3).

Smith and Curry (2005) have identified 12 tips for supporting students in the context of distance where tip 1 has particular value for this study. Tip 1 recommends that one identifies areas of support and train the support providers as to what is required of them. Included in these recommendations are administrative (processes and procedures of the institution) and technical (for example, computer access) support; teaching and learning support, which also refers to the learning needs and learning styles of students; mentor support; and welfare and counselling services because of the impact of studying on the students and family. Osman and Castle (2006:517) have used Morrow's (1993/1994) barriers which impact on students from previously disadvantaged educational backgrounds, namely, physical access arising from students' personal life situation, such as work and home commitments, as well as from the institution itself, such as negotiating entry requirements and appropriate courses and credits; 
and epistemological access or the prior knowledge that students have acquired through school or work and the fit with academic (thereby dominant) standards.

\section{METHODOLOGY OF THE PRESENT STUDY}

At UWC the researcher followed the qualitative research approach and selected the focus group as a data-collecting method in order to become familiar with students' perceptions of their learning experiences and notions of support. The focus group method is viewed as essential for gaining understanding of people's opinion on their lived experiences resulting from the interaction amongst group members (Greeff in De Vos, Strydom, Fouché \& Delport, 2007:303). Most important for this study is that focus groups provide a process of "sharing and comparing" amongst participants, as well as instances where the researcher aims to comprehend differences between people or groups, for example, traditional and non-traditional access groups (Greeff in De Vos et al., 2007:301). The researcher initially recruited eight participants consisting of RPL and traditional access students. Volunteer sampling was followed, firstly, because of the few RPL students (4) and a large number of traditional access students (70) in the first-year Social Work class (Strydom \& Delport in De Vos et al., 2007:330). Secondly, the sample was dependent on the interest and availability of the students, Ultimately, seven students attended and participated in the focus group on the day.

\section{DISCUSSION OF RESEARCH FINDINGS}

Research findings and discussion are presented in terms of the two research questions.

\section{PRIOR LEARNING EXPERIENCES AND KNOWLEDGE}

Students could identify five knowledge sources from where they had received valuable knowledge and skills. The table below delineates the source of their skills and knowledge and what they gained from these sources.

\section{TABLE 2}

\section{SOURCES OF PRIOR LEARNING}

\begin{tabular}{|c|c|c|}
\hline $\begin{array}{l}\text { 1. FAMILY, NOTABLY } \\
\text { MOTHER }\end{array}$ & \multicolumn{2}{|c|}{$\begin{array}{l}\text { - Life skills (how to cope with life) } \\
\text { - Sense of responsibility } \\
\text { - Acceptance of yourself and others }\end{array}$} \\
\hline $\begin{array}{l}\text { 2. PREVIOUS WORK } \\
\text { EXPERIENCE }\end{array}$ & \multicolumn{2}{|c|}{$\begin{array}{l}\text { - Team work } \\
\text { - Organising } \\
\text { - Being critical and non-accepting of what people tell you } \\
\text { - Handling yourself and gossip of others }\end{array}$} \\
\hline \multirow[t]{2}{*}{ 3. $\mathrm{SCHOOL}$} & \multicolumn{2}{|c|}{$\begin{array}{l}\text { - To listen } \\
\text { - To communicate with other learners, teachers }\end{array}$} \\
\hline & $\begin{array}{l}\text { - Peer counselling } \\
\text { - Confidence }\end{array}$ & $\begin{array}{l}\text { From participation in extra-curricula } \\
\text { activities such as drama, peer coun- } \\
\text { selling programme, being a prefect. }\end{array}$ \\
\hline 4. PREVIOUS COURSES & \multicolumn{2}{|l|}{ - Presentation skills } \\
\hline $\begin{array}{l}\text { 5. OTHER PEOPLE AS } \\
\text { MOTIVATORS }\end{array}$ & \multicolumn{2}{|c|}{ - Inspired to achieve, to take leadership by observing others } \\
\hline
\end{tabular}


These kinds of learning can be linked to mode 3 learning identified by Rochford (2007:93) as "out-of-school experiences", but as the participants were mostly just out of school they did in fact highlight what they had learnt from extracurricular activities and not from a non-formal learning environment. Rochford describes this as "lifeplace learning". The students not only identified skills - for example, presentation and organising skills - but also emotions and attitudes, for example, confidence, acceptance of yourself and others, and being inspired to do something out of the ordinary routine of their lives. These responses link with what Kolb (1984) referred to as concrete experiences, where practical experiences spark off learning and in reflective observation the students' showed that they could make meaning out of the experiences and could therefore conceptualise them (abstract conceptualisation) (Moore \& Van Rooyen, 2002).

\section{AREAS WHERE SUPPORT WAS REQUIRED}

Students' descriptions of their first day at University of confusion and helplessness may not be "out of the ordinary". It is a new experience and so a measure of anxiety and trepidation is expected. The role that the University can play in alleviating some of the confusion as experienced by the students, however, is related to the University's administrative processes and procedures. The students evaluated these processes negatively, and in the process of the focus group discussion they could not transcend the negative impact of this on their ability to adapt to the University and enjoy the new experience. In this respect, Geyser (2001) had noted that adult learners who are entering university for the first time would require an environment that is particularly supportive.

"It is 8 months and we are still running around asking questions, getting the run around."

"We are lost in a big group" and "small fish in a big pond" or confused (because venues were unclear, unstipulated, or not found, as well as registration not completed at the time when classes started.)

The following are some of the administrative processes that were particularly important to them:

- Application and registration process must be efficient (it was very time consuming) and transparent (give reasons for accepting and rejecting);

- Competent and informed staff to assist with information and advice about, for example, registration procedures and required modules;

- Efficient bursary application (Department of Social Development) and payout;

- Residency must be awarded prior to arrival to prevent additional student confusion;

- Departmental organisation for specific elective courses to avoid, for example, class clashes; little feedback on assignments; expensive prescribed textbooks only used for 2 weeks.

Another factor identified to encourage student integration was that teachers should have positive attitudes, which was also identified by students in New Zealand (New Zealand Ministry of Education, 2005). One student stated that a lecturer (in a certain elective course) was insulting and demotivating to students. He described them as "Lecturers who break you down". Accordingly students no longer attended that class regularly. Students also felt disrespected when certain lecturers came to class unprepared. "Lecturers to be prepared. Have a plan B if technology fails." 
Smith and Curry (2005) also note technical support as another crucial factor in alleviating stress in the British student's life. This aspect was particularly focused on in the SA group. They were frustrated at the limited number of computer labs, their inaccessibility and the rules (or the lack of rules) that governed their usage. This is a summary of what was said:

- Certain computer labs reserved for students doing particular courses; no rules for computer usage (students using computers for Facebook); computers that do not work very well. Students wanted the Social Work department to construct a computer lab for use only by Social Work students.

Students had fragmented notions of what support they required. As can be seen from the following points, these notions would appear to link directly with their personal circumstance:

- Guidance with studying and purposeful reading (particularly from one RPL student);

- Support from Social Work class was limited to specific instances. Students mainly relied upon themselves;

- Support for emotional needs. "Somebody to talk to";

- Overloading in $3^{\text {rd }}$ term, which impacted on family life and ability to do well.

"There was a time I felt this is too much for me. I have to cook, work, do assignments and I just have to do everything!"

Smith and Curry (2005), in their tip number 1 for supporting distance-learning students, recommend welfare and counselling services because of the impact of study on the student and the family. The students felt the weight of their responsibilities to themselves and significant others in their lives. In the South African context this would point to Morrow's barriers of physical access arising from the impact that students' personal lives, with their responsibilities in their homes and outside work, have on their academic work (Osman \& Castle, 2006).

The students could access the following institutional structures in terms of what they needed: student counselling, tutors in their residence, Social Work tutors, Social Work supervisors (in terms of the last three mentioned, students felt that the quality of support provided depended on the personality of the supervisor, ability and the motivation to help), outside help (where they received help before they came to university, e.g. principal at school), computer labs, writing centre and bio-kinetics. The students were positive about the formal support structures that the University did provide; however, these were insufficient. Students felt that it was their responsibility to form study groups amongst their fellow students. They felt that it was the University's responsibility to provide a Social Work computer lab, social workers as student counsellors, and classes on how to study.

\section{CONCLUSION}

The overwhelming impression of the students' responses was of confusion and helplessness in their semester at a HEI. This they attributed largely to their perception of the University's administrative processes and procedures as being obscure and not user-friendly. Furthermore, those procedures were incoherent and not complementary amongst the various faculties and departments. Students' negativity about university administrative processes is not unique to this institution; it is indeed a common experience by students. Both the New Zealand Ministry of Education (2005) and Smith and Curry (2005) in Britain identify sound administrative processes as important factors in contributing to student throughput and success in the long term, but also to foster student integration in the short term. 
Students' opinions and feelings reflected an environment less than supportive for their integration and adaptation in the institution to ensure throughput and success. Students were then compelled to use the kinds of knowledge and skills that they had developed prior to entering university to push through these barriers and to survive. Cantwell and Scevak (2004) refer to epistemological and cultural knowledge that impact on the success of especially RPL students; however, the UWC students used this knowledge to their advantage. They questioned, they observed, they discovered and they accessed what they needed to in order to break especially epistemological barriers (Osman \& Castle, 2006). Cantwell and Scevak (2004) also noted the success of mature entry students. The Social Work RPL students can be deemed to be successful in terms of retention, persistence, completion and graduation.

According to the data collected in the SA focus group discussion, students responded easily to the challenges and positive experiences of one another. There was a high degree of commonality amongst participants in terms of their experiences of the administrative processes at the University and their opinion about support that they needed. It was clear that the RPL students did not feel differently from the traditional access students about the support that was required. It was also clear that the RPL students did not feel the need for "added" support and that the generic structures already in existence were sufficient. There were also individual needs not shared by the other participants in terms of the RPL student's need for reading and study support. This suggests a learning and support plan that suits individual's needs and not necessarily a "one size fit all" approach. This notion is also supported by the Rural Education Access Programme research report (REAP, 2008) on success factors for disadvantaged students in HEIs.

The existing curriculum and resultant content of the BSW courses do not, firstly, elicit prior knowledge, and consequently do not make space for these skills and knowledge to be the springboard for further learning. In the non-valuing and non-acknowledgment of the students' prior knowledge, we negate its importance. Therefore we are not increasing students' confidence and self-worth because we are inadvertently keeping them hidden. If we want more from RPL then it must inform curriculum and learning outcomes, otherwise it will remain on the margin, not fulfilling its redress and equity claims (Moore \& Van Rooyen, 2002). Furthermore, we do not meet the principles of lifelong learning by not cementing the link between learning and real life (Evans, 2006). The continuing challenge is to provide opportunities for active experimentation to complete the learning cycle now that the students are at university (Kolb, 1984).

By not valuing the prior experiences of adult learners, we contradict the approach of andragogy proposed by Knowles (Conner, 2004). We may still be stuck in viewing students as child-like, as not having lived an eventful, mature life prior to entering university. Knowles believed that the experiences of adults should be the focal point of learning, but this has not been translated into curriculum design, learning outcomes, mode of instruction and teacher attitude. While the principles of self-directed learning and the use of learning contracts may not fit the South African educational context (Cretchley \& Castle, 2001), the contribution of Knowles to adult learning lies in his seminal work on adult learning principles. The knowledge and skills identified by the participants also point to Morrow's point about difficulty of epistemological access as being a barrier in terms of the disparity between prior knowledge and dominant academic standards (Osman \& Castle, 2006). 


\section{REFERENCES}

AMSTUTZ, D. 1999. Adult learning: moving towards more inclusive theories and practice. New Directions for Adult and Continuing Education, 82:19-32.

ATHERTON, J. 2005. Learning and teaching: experiential learning. Available: http//www.learningandteaching.info/learning/experience.htm. [Accessed: 14/08/2008].

BREIER, M. 2007. Recognising phronesis or practical wisdom in the recognition (assessment) of prior learning. Paper presented at the $5^{\text {th }}$ International Conference of Researching Work and Learning, Cape Town, 2-5 December 2007.

CANTWELL, R. \& SCEVAK, J. 2004. Engaging university learning: the experiences of students entering university via recognition of prior industrial experience. Higher Education Research \& Development, 23(2):131-145.

CONNER, M. 2004. Andragogy and pedagogy. Ageless Learner 1997-2004. Available: http://agelesslearner.com/intros/andragogy.html. [Accessed: 15/08/2008].

CRETCHLEY, G. \& CASTLE, J. 2001. OBE, RPL and Adult Education: good bedfellows in higher education in South Africa? International Journal of Lifelong Education, 20(6):487501.

DYSON, C. \& KEATING, J. 2005. Recognition of prior learning: policy and practice for skills learned at work. In: Skills, knowledge and employability (Skills Working Paper No. 21). Geneva: International Labour Office.

EARLE, N. 2007. The new profile of social work education in South Africa: factors impacting on the translation of equity access to equity success. Paper presented at the $5^{\text {th }}$ International Conference of Researching Work and Learning, Cape Town, 2-5 December.

EVANS, K. 2006. The rainbow concept of lifelong learning (thematic review). British Educational Research Journal, 32(3):527-534.

FEBRUARY, C. \& KOETSIER, J. 2007. What 'support' and 'success' means to a group of working adults within one Faculty at a South African Higher Education Institution. Paper presented at the $5^{\text {th }}$ International Conference of Researching Work and Learning, Cape Town, 2-5 December.

GEYSER, H. 2001. RPL: lessons from abroad. South African Journal of Higher Education, $15(2): 30-36$.

GREEFF, M. 2007. Sampling and pilot study. In: DE VOS, A., STRYDOM, H., FOUCHÉ, C. \& DELPORT, C. 2007. Research at grass roots for the social sciences and human service professions $\left(3^{\text {rd }}\right.$ ed $\& 3^{\text {rd }}$ Impression). Pretoria: Van Schaik Publishers.

HALIFAX DECLARATION FOR THE RECOGNITION OF PRIOR LEARNING. 2001. Joint National Conference for Prior Learning Assessment and Qualification Recognition. Halifax, Nova Scotia, Canada: 28-30 October.

HARRIS, J. 2000. RPL: power, pedagogy and possibility - conceptual and implementation guides. Pretoria: Human Sciences Research Council.

INDEPENDENT ONLINE. 2008. Social work, 'a scarce skill'. July 21. Available: Www.iol.co.za. [Accessed: 19/08/2008]. 
KISTAN, C. 2002. Recognition of prior learning: a challenge to higher education. South African Journal of Higher Education, 16(1):169-173.

MOORE, A. \& VAN ROOYEN, L. 2002. Recognition of prior learning as an integral component of competency-based assessment in South Africa. South African Journal of Education, 22(4):293-296.

NATIONAL MASTER SCARCE SKILLS LIST FOR SOUTH AFRICA, 2007. Available: www.skillsportal.co.za/download_files/professional/NSDS-Scarce_Skills_List2007.doc.

[Accessed: 19/08/2008].

NEW ZEALAND MINISTRY OF EDUCATION, 2005. Supporting students in tertiary study: a summary of a synthesis of research on the impact of student support services on student outcomes in undergraduate tertiary study (Rivers, J. (ed)).

OSMAN, R. \& CASTLE, J. 2006. Making space for adult learners in higher education. South African Journal of Higher Education, 20(4):515-527.

RALPHS, A. \& BUCHLER, M. 1998. The NQF and the recognition of prior learning. Joint Education Trust Bulletin, 8:10-13.

ROCHFORD, K. 2007. Mode 3 knowledge systems and lifeplace learning experiences. Paper presented at the $5^{\text {th }}$ International Conference of Researching Work and Learning, Cape Town, 2-5 December.

RSA: SOUTH AFRICAN QUALIFICATIONS AUTHORITY. 2002. Recognition of Prior Learning: The Development, Implementation and Quality Assurance of RPL Systems, Programmes and Services by ETQAs, Assessors and Providers. Government Gazette, 4 March.

RSA: SOUTH AFRICAN QUALIFICATIONS AUTHORITY ACT. 1995. Available: www.saqa.org.za/docs/policy/rpl01.pdf. [Accessed: 23/04/2007].

RSA: WHITE PAPER ON EDUCATION AND TRAINING: Notice 196 of 1995. Department of Education. Parliament of the Republic of South Africa. Cape Town, 15 March 1995.

RSA: HIGHER EDUCATION ACT OF SOUTH AFRICA: Act 101 of 1997. Government Gazette, 19/12/1997.

RURAL EDUCATION ACCESS PROGRAMME. 2008. Factors that facilitate success for disadvantaged higher education students: an investigation into approaches used by REAP, NSFAS and selected higher education institutions. Executive Summary. (Prepared by Jones, B., Coetzee, G., Bailey T. \& Wickham, S.)

SKWEYIYA, Z. 2008. Former Minister of Social Development. Welcome Address. 34 ${ }^{\text {th }}$ Biennial Congress of the International Schools of Social Work (IASSW). Transcending global-local divides: challenges for social work education and practice. Programme \& Abstracts. Durban, 20 July.

SMITH, L. \& CURRY, M. 2005. Twelve tips for supporting online distance learners on medical post-registration courses. Medial Teacher, 27(5):396-400.

STRYDOM, H. \& DELPORT, C. 2007. Sampling and pilot study. In: DE VOS, A., STRYDOM, H., FOUCHÉ, C. \& DELPORT, C. 2007. Research at grass roots for the social sciences and human service professions $\left(3^{\text {rd }}\right.$ ed $\& 3^{\text {rd }}$ Impression). Pretoria: Van Schaik Publishers. 
UNIVERSITY OF THE WESTERN CAPE: DIVISION OF LIFELONG LEARNING Introducing the Recognition of Prior Learning (RPL) at UWC. Available: www.uwc.ac.za/dll/rpl /about.htm. [Accessed: 23/04/2007].

UNIVERSITY OF THE WESTERN CAPE. 2008. General Calendar.

UNIVERSITY OF THE WESTERN CAPE. 2008. University Calendar Part VIII.

ZUHAIRI, A., ADNAN, I. \& THAIB, D. 2007. Provision of student learning support services in a large-scale distance education system at Universitas Terbuka, Indonesia. Turkish online Journal of Distance Education, 8(4).

Ms Glynnis Z. Dykes, Department of Social Work, University of the Western Cape, Bellville, South Africa. 